\title{
The Significance of Edutainment Concept in Video-Based Learning in Proposing the Elements of Educational Music Video for Children's Learning
}

\author{
https://doi.org/10.3991/ijim.v16i05.23711 \\ Hanis Salwani Othman ${ }^{(凶)}$, Syamsul Bahrin Zaibon, Ahmad Hisham Zainal Abidin \\ School of Creative Industry Management and Performing Arts, \\ Universiti Utara Malaysia, Kedah, Malaysia \\ hanissalwani@uum. edu.my
}

\begin{abstract}
A video-based learning (VBL) has long practically been used in the education environment to help students enhance their level of understanding. Educational content for VBL has been widely produced on various platforms to support achieving the optimum level of student performance. Additionally, the concept of edutainment using video in education is gaining traction, particularly in children's learning. Implementing the edutainment notion into the learning process is a critical component of successful learning. Previous research has examined the beneficial effects of edutainment using video for learning purposes. It has been shown to improve the effectiveness of the learning process and generate enjoyable learning experiences for students. As the paper is aimed at children, the educational music video (EMV) can capture their attention even more than a standard educational video does due to its interactive content. However, studies on edutainment for educational music videos, in particular, have not been studied much. Thus, the objective of this paper is two-fold; i) to review and discuss the conceptual approach of edutainment and its significance towards student learning experiences, and ii) to propose the component and element of edutainment in the EMV for children learning. The findings of this study outline the characteristics of edutainment that can be utilised as criteria for selecting the finest EMV for children's learning.
\end{abstract}

Keywords — edutainment, educational music video, video-based learning

\section{Introduction}

In recent years, video-based learning (VBL) is gaining more attention in the field of education. In fact, the pandemic of coronavirus disease (COVID-19) has emphasised the importance of VBL in facilitating the learning process and achieving learning objectives more efficiently. The demand of self-directed online learning using video 
is beginning to be practised seriously owing to state of emergency with movement restriction order measures being applied by the government in preventing the spread of COVID-19. Besides, prior studies shows that using VBL media can significantly improve student learning results when learning online [1]-[3]. Basically, VBL refers to "the learning process of acquiring defined knowledge, competence, and skills with the systematic assistance of video resources" [4]. VBL can be practiced when educational video content is being used as learning materials. The different purposes for using video materials include providing examples of best practices, encouraging discussions, and enhancing blended learning environments [5]. Additionally, with the introduction of the video-sharing sites, educational videos are easier to get, which has increased their production. Due to the massive volume of educational videos produced nowadays, it has created an excellent opportunity for academic practitioners to maximise the use of this learning material with students. The independent educators also strive to explore various approaches and strategies to achieve quality learning other than following the standard curriculum designed by the education department. The approaches include diversifying digital learning support materials such as EMV in the learning process.

Nevertheless, the EMV should be integrated with the edutainment concept when it comes to children's learning. Children are more attracted to a fun learning environment that emphasises the element of enjoyment and amusement. [6] mentioned that edutainment in learning depends on the belief that the learning process is fun. One of the strategies to achieve quality children's learning is implementing the edutainment concept in the learning process. This concept can be integrated with digital learning support materials like EMV. The advantage of implementing the edutainment concept is to create a fun learning process so that students understand the idea of learning readily without the sense that they are learning. For example, [7] argued that edutainment in learning was supposed to encourage children to enhance their memorization, enrich the learning process, and offer flexibility using multimedia games. On top of that, [8] claimed that edutainment in heritage multimedia relies on affective and sensory learning, which could help children reconnect awareness and caring more solidly. Many studies have been conducted previously to implement edutainment in learning, but to what extent can this concept impacted students, particularly for children's learning using EMV.

This paper aims to contribute to the research on VBL, more specifically, EMV. The objectives of this paper are twofold: first, an extensive literature review was conducted to ascertain the significance of the edutainment concept in learning and its impact on students. The second objective is to use comparative analysis to discover the component and elements of edutainment in EMV for children's learning. Section 2 provides an overview of edutainment and how it has been integrated into the learning process particularly in educational videos. Section 3 offers a detailed explanation of the study's method, including a rigorous comparative analysis and expert validation process. Additionally, Section 4 summarised the results of the comparative analysis and expert review. Finally, Section 5 contains a concise conclusion that summarises the whole substance of the study. 


\section{Edutainment in learning environment}

\subsection{Edutainment concept in learning}

To understand the value of edutainment in education, it is necessary first to grasp the concept of learning while entertaining in general. This concept involves a comprehension of the notion of edutainment and its implementation in educational applications. Since edutainment could be implemented for different fields of study, the paper is scoped to explore its significance in the education context in other learning applications or systems. Edutainment is a combination of educational and entertainment words that emphasise learning while entertaining. This approach has existed for decades, as seen by the widespread use of edutainment, particularly in industrialised and emerging countries, in conjunction with technological growth [9]. A few meanings of edutainment have been interpreted in the previous studies as the main foundation for this concept. [10] defined edutainment as a derived word that describes a mixture of education and entertainment or, in other words, is a marriage of education with entertainment. [11] described edutainment as a mixture of sound, animation, image, video, and writing, which promoted fun and learning to learners. Besides, edutainment can also be defined as a concept of enjoyable learning that serves as a tool for teachers or parents to educate and entertain their children at the same time [12]. Learning in Edutainment is taught to integrate various factors, including media, the classroom environment, and several activities, to promote happiness while playing and learning [13].

In more detail, [14], [15] state that education and entertainment co-occur where it was initially used to produce video games or commercial CD ROMs for educational purposes to help children benefit the knowledge while playing. On top of that, [16] defined edutainment as "pleasure or positive experiences that a learner hopefully desires. The pleasure can result not only from the entertaining and interesting content itself but also from the satisfaction of getting problems solved, especially in games". From these definitions, it can be inferred that edutainment is a learning concept that combines two significant parts, namely, education and entertainment. It can be happened concurrently and enable the learning process to be entertaining. As can be seen, edutainment is frequently used in games applications to promote learning while entertaining. Students who can adapt to a pleasurable learning environment have a greater chance of achieving a higher level of understanding.

Due to that, edutainment is considered an appropriate approach for promoting learning and attaining high-quality children's learning. In addition, children in this millennial age are more likely to use technology to help them learn. [17] also supported those children of millennials are being exposed to many technologies' features such as hightech gadgets, the internet, and social networks. Besides, [18] supports the objective of edutainment to attract the student's attention and interest and enable them to focus on events and teaching materials during the learning process. Other than that, [19] revealed that edutainment in games for language learning was positively influenced young learners. In her study, she tested 181 participants from Turkish state primary schools, including 121 fifth-grade pupils and 60 English teachers. The findings indicated that playing games are an effective method of learning English, and the majority 
of participants felt that children easily grasp the language while playing games. When teaching children as learners, it is important to acknowledge their natural proclivity for game playing. When it comes to entertainment activities, their motivation is always at its highest. Besides, sustaining a high level of motivation is critical for the learning process to succeed. Thus, it is clear that the element of enjoyment in edutainment can considerably assist learning, particularly when the target learner is children.

Other than that, [20] specified the benefit of edutainment in learning in presenting enjoyable, calm, and pleasing experiences to children. It indirectly encourages children to develop a positive relationship with their teachers. Meanwhile, there are a few considerations to make while dealing with edutainment technology. It is necessary to encourage the students to pay attention, arouse their interest in the subject being studied, and actively participate in the learning process [21]. Thus, students and teachers should collaborate to help students develop a strong interest and drive for accomplishing quality learning through technological edutainment. Nevertheless, this does not mean that the quality of learning depends on the application of edutainment merely. According to [21], edutainment encompasses a relatively small portion of the educational process where it only contributes to learning diversification without demanding total modification of the traditional learning model. Yet, edutainment promotes positive learning outcomes such as engagement, motivation to study, enjoyable learning experiences, and a desire to continue learning and applying knowledge [22]. In fact, edutainment contributes to the learning process by incorporating the concept of learning while entertaining. Children learn more readily when the learning environment is enjoyable.

\subsection{Edutainment approaches}

Edutainment can be implemented with entertaining varieties such as multimedia applications, websites, music, films, video, computer games, and television programs developed to educate [10]. As referred to these claims, edutainment products and applications have been diversified, which in line with the current technological developments. It can be distributed on various platforms such as online video-sharing, websites, video games, television programs. Most of the products that implement the edutainment conceptualised as a video presentation which aimed to support and promote the concept of learning while entertaining. However, various other approaches can be used for learning purposes. For example, [23] used the song as edutainment to teach the English language to high-school students. The findings of his study revealed that the learning process that uses song could make the students actively engage in the class. Besides, the emphasis on entertainment elements such as amusement and joy had become the motif for people to enjoy the activities mentally or physically. For instance, traditional teaching sessions that include mere lectures could be dull, causing students to lose interest.

On top of that, playing activity also become a part of the edutainment approach involved in the learning session. These activities do not concern entertaining only but could also focus on exercising the new knowledge more easily [24]. After a thorough explanation of the edutainment notion, the following section discusses the substantial influence of edutainment on educational videos. The outcome is crucial for the next 
phase: identifying the component and element of edutainment in EMV for children's learning. Hence, the following section discusses the study method in detail.

\subsection{Edutainment in educational video}

The concept of edutainment was also emphasised in educational videos to increase the effectiveness of the learning process. Recent research has positively influenced learners when educational videos are used as a supplemental learning medium. However, as the studies on edutainment for educational videos is insufficiently explored specifically for children's learning, these studies are aimed at students in various ages in general. Edutainment in the educational video can enhance learning at all stages of education, including preschool, secondary, and elementary school, and tertiary level (academic level following the completion of secondary education). A study by [25] stressed the need to integrate edutainment into American mathematics television shows, specifically Numb3rs, to promote mathematical problem-solving activities. The exploratory study discovered that the participants, who are pre-service mathematics teachers, indicated that the edutainment learning tool had influenced their overall way of thinking. By extension, the greater one's mathematical problem-solving abilities, the greater one's chances of developing critical-creative thinking. Thus, the study discovered that including edutainment in learning can help students establish critical-creative thinking skills, increase engagement, and transition from fixed to growth mindsets.

Other than that, the utilisation of educational videos as a learning medium, particularly for young learners, should highlight the humorous element to pique their interest. [26] demonstrate that videos with hedonistic elements can increase retention by an average of $6 \%$, equating to a half-grade improvement for many students. Besides, the authors revealed that hedonic video content shown at the beginning of the class could develop a more positive emotional state. The chance to increase student's retention is also high as long as the video is aligned to the learning objective. Meanwhile, in health education, the role of edutainment in the educational video has also been demonstrated to be beneficial. For example, [27] discovered that exposing school children to animated videos as a part of health education interventions was significantly effective in rural settings. The video's edutainment approach incorporates drama, song, and poetry, allowing the audience to participate directly with the characters. All of these activities prompted the children to participate enthusiastically during the show. It unequivocally demonstrates that edutainment has the potential to emotionally and physically engage children.

Additionally, not only is edutainment more entertaining, but it is also more remembered for learners. According to [22], edutainment in educational video help students focus on the content and possibly promote long term memory recall as it contains various stimuli such as images, sounds, and characters. The author also suggested cloud-based animation software in creating educational videos such as Powtoon and GoAnimate. By utilising these tools, the video creation process will be simplified and accelerated, as more features will be available to help make the video material more meaningful. Another study, which also used the Powtoon software, established the importance of edutainment implementation in educational videos. [28] point out that 
Powtoon can help students who struggle with reading concepts enhance their English reading abilities and raise their enthusiasm and motivation for studying. Based on the interview and observation conducted in this study, the students responded positively towards animated video using Powtoon. The learner expressed satisfaction with the learning experience, describing it as easy and attractive. Additionally, they can improve their knowledge of the learning content, mastered the vocabulary, increased their reading comprehension, and demonstrated an eagerness to learn more about the English language. Thus, it showed that edutainment in educational video can have a positive influence on children's learning, especially interest, concentration, as well as on their overall behavior in school.

As this study focused on children's learning, EMV is seen to gain more interest in children. According to [29], music video creation could be used for informal education to offer students a new technique in exposing themselves to become better media performers and users. Besides, some practical advantages of using music video in learning were mentioned by [30] in terms of availability, accessibility, focus retention, flexibility, cost-effectiveness, social media access, and relevancy. The usefulness of music video in education learning is also undeniable even though the initial aim of music video production is mainly being used in the film and music industry as a promotional marketing tool. Therefore, this study identifies and proposes edutainment components and elements of EMV for children's learning based on the substantial impacts of edutainment in educational videos. Section 3 elaborates on these processes in depth.

\section{Study method}

A comparative analysis was conducted to identify the components and elements of edutainment for EMV from kinds of literature. It comprises a variety of educational videos that are utilised to supplement the learning of all students. In terms of data resources, secondary data are ideal for comparative analysis because they span more extended periods and cover a greater geographical area. Once the elements were identified, an expert review was conducted to validate the proposed elements.

\subsection{Comparative analysis}

To initiate this study, comprehensive literature searches were conducted to gather related articles concerning edutainment in the education field from global journals and databases. These databases include Google Scholar, Research Gate, ACM Digital Library, and Mendeley Library. A total of 16 studies that relate to educational videos were selected to be reviewed comprehensively. While searching the intended articles, several keywords were identified to ensure the return results are more specific and suit the aim of this study. The keywords include edutainment, education entertainment, educational video, interactive video and other related keywords. There are over 50 articles on edutainment from various fields and interests in the early stages of the search, including virtual reality, game-based learning, consumer behaviour, and entrepreneurship. In searching for more specific articles, a particular theme was applied manually, which suits the aim of the study. As a result, 16 studies fulfil the purpose of this study 
and selected for comparative analysis [31]-[46]. These articles were focused on the edutainment concept and approach for VBL in the education context.

\subsection{The proposed elements of edutainment feature}

The component of Edutainment Feature refers to the element of entertainment incorporated into the content of EMV that aims to provide the opportunity to experience the learning while entertaining concepts to the learner. Meanwhile, the elements for this component refer to the aspect that can trigger a positive feeling for the learner while using the EMV. These elements could become the added values to EMV content because they can attract the attention and interest of viewers to choose the right EMV content. There are three elements for sub-component Emotional Attraction, as listed below:

i. Musical Interest: the term refers to the appeal of musical sound in video learning to attract student attention and entertaining them.

ii. Speech Element: the term refers to the speech technique used in video learning, such as voice tone, speed, and formality.

iii. Character Representation: other than using animated characters, the actual human can also be used as character assist. So, use a person or so-called talking head (speaker/character assist) with a face and shoulder shot if necessary.

Having described the Edutainment feature elements, each statement mentioned in the selected studies has been reviewed and analysed to discover its commonality. Table 2 shows the tabulation of the findings from the comparative analysis for these mentioned statements. This study uses a set of indicators shown in Table 1 to determine the suitability of the component and its elements.

Table 1. Indicator of component and element selection

\begin{tabular}{|l|l|l|}
\hline Indicator & \multicolumn{1}{|c|}{ Description } & \multicolumn{1}{c|}{ Condition of Classification } \\
\hline$\square$ & $\begin{array}{l}\text { Compulsory to } \\
\text { apply }\end{array}$ & $\begin{array}{l}\text { The component is compulsory to be applied when all models }(100 \%) \\
\text { or majority of models appear in the row }(50 \%-99 \%)\end{array}$ \\
\hline$\square$ & $\begin{array}{l}\text { Recommended to } \\
\text { apply }\end{array}$ & $\begin{array}{l}\text { The component is recommended to be applied when fewer models } \\
(1 \%-49 \%) \text { or no model appear in the row }(0 \%)\end{array}$ \\
\hline
\end{tabular}

Table 2. Comparative analysis of elements for musical interest in existing studies

\begin{tabular}{|c|c|c|c|c|c|c|c|c|c|c|c|c|c|c|c|c|c|c|c|}
\hline \multirow[b]{2}{*}{ Element } & \multicolumn{16}{|c|}{ Selected Existing Studies } & \multirow{2}{*}{ हैّ } & \multirow{2}{*}{ 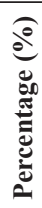 } & \multirow{2}{*}{ 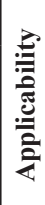 } \\
\hline & 1 & 2 & 3 & 4 & 5 & 6 & 7 & 8 & 9 & 10 & 11 & 12 & 13 & 14 & 15 & 16 & & & \\
\hline Musical Interest & $\mathrm{Y}$ & $\mathrm{Y}$ & - & - & - & - & - & $\mathrm{Y}$ & - & - & - & - & - & $\mathrm{Y}$ & - & $\mathrm{Y}$ & 5 & 31 & $\square$ \\
\hline Speech Element & - & $\mathrm{Y}$ & $\mathrm{Y}$ & - & $\mathrm{Y}$ & $\mathrm{Y}$ & - & $\mathrm{Y}$ & - & $\mathrm{Y}$ & - & $\mathrm{Y}$ & $\mathrm{Y}$ & $\mathrm{Y}$ & $\mathrm{Y}$ & $\mathrm{Y}$ & 11 & 69 & - \\
\hline $\begin{array}{l}\text { Character } \\
\text { Representation }\end{array}$ & - & - & - & - & $\mathrm{Y}$ & $\mathrm{Y}$ & - & - & - & $\mathrm{Y}$ & - & $\mathrm{Y}$ & $\mathrm{Y}$ & - & - & $\mathrm{Y}$ & 6 & 38 & $\square$ \\
\hline
\end{tabular}

Note: Y refers to Yes. 


\subsection{The proposed elements of activity}

This component refers to the interaction that occurs when the children are dealing with EMV content. The implementation of the edutainment concept, namely learns while entertain, has been a factor in this interaction. Through these interactions, the viewer focuses on learning merely and encourages them to participate more actively during the learning process. There are three elements for the sub-component of 'interaction opportunities', as described below:

i. Social Interactivity: allow functional interactivity and physical interaction of students in the learning environment while dealing with video content.

ii. Interactive Questioning: refers to the question method used in learning video as learning reflection.

iii. Expand learning space: apart from directly accepting what is displayed in the video content, it allows students to create their imagination.

All these elements allow the learner to interact better during the learning process, especially for group learning (i.e., a group of people dealing with the same EMV content). Most of the previous studies also emphasised the elements of interaction opportunities shown in Table 3 (the tabulation of the results from the comparative studies of previous studies). The same indicator in Table 1 applied for proposing the elements of Activity. It clearly shows that previous studies also have the same concern where this element is significant to the content of EMV as a whole. Meanwhile, Figure 1 shows the proposed sub-component and elements for 'edutainment feature' and 'activity' as a whole.

Table 3. Comparative analysis of elements for interaction opportunities in the selected studies

\begin{tabular}{|c|c|c|c|c|c|c|c|c|c|c|c|c|c|c|c|c|c|c|c|}
\hline \multirow[b]{2}{*}{ Element } & \multicolumn{16}{|c|}{ Selected Existing Studies } & \multirow{2}{*}{ 焉 } & \multirow{2}{*}{ 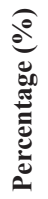 } & \multirow{2}{*}{ 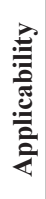 } \\
\hline & 1 & 2 & 3 & 4 & 5 & 6 & 7 & 8 & 9 & 10 & 11 & 12 & 13 & 14 & 15 & 16 & & & \\
\hline Social Interactivity & - & - & - & - & - & $\mathrm{Y}$ & $\mathrm{Y}$ & - & - & Y & $\mathrm{Y}$ & - & - & $\mathrm{Y}$ & $\mathrm{Y}$ & $\mathrm{Y}$ & 7 & 44 & $\square$ \\
\hline $\begin{array}{l}\text { Interactive } \\
\text { Questioning }\end{array}$ & - & - & - & - & - & $\mathrm{Y}$ & $\mathrm{Y}$ & - & - & $\mathrm{Y}$ & $\mathrm{Y}$ & - & - & $\mathrm{Y}$ & $\mathrm{Y}$ & $\mathrm{Y}$ & 7 & 44 & $\square$ \\
\hline $\begin{array}{l}\text { Expand Learning } \\
\text { Space }\end{array}$ & - & - & - & - & - & - & $\mathrm{Y}$ & - & - & $\mathrm{Y}$ & - & - & - & $\mathrm{Y}$ & $\mathrm{Y}$ & $\mathrm{Y}$ & 5 & 31 & $\square$ \\
\hline
\end{tabular}

Note: Y refers to Yes.

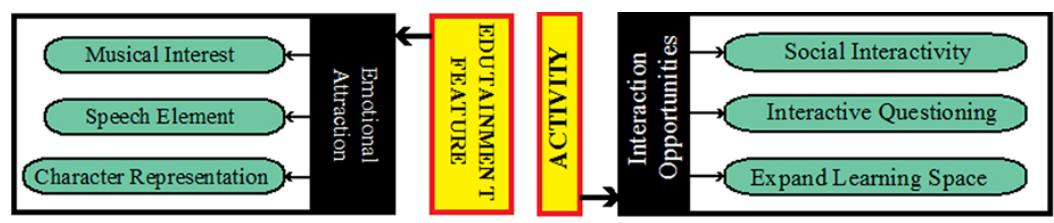

Fig. 1. Proposed sub-component and elements of edutainment feature and activity 


\subsection{The validation process of the proposed elements}

An expert review was conducted to validate the proposed component and elements of edutainment in EMV. The process was conducted qualitatively, where 11 experts were invited to participate in the reviewing process. This amount is sufficient for this study as underlined by [47] and [48].

Participant's profile and setting. The experts are from various fields and expertise such as Multimedia Studies, Instructional Design and Technology, Media Studies, or Educational Technology. The experts must have an academic qualification in Master or $\mathrm{PhD}$ and involved in related fields for at least five years of experience. The detail for each expert is listed in Table 4.

Table 4. The list of experts with demographic profile

\begin{tabular}{|c|c|c|c|c|c|}
\hline Expert & Gender & Education & $\begin{array}{l}\text { Field of } \\
\text { Expertise }\end{array}$ & $\begin{array}{c}\text { Year of } \\
\text { Experience }\end{array}$ & Affiliation \\
\hline A & $\mathrm{F}$ & $\mathrm{PhD}$ & $\begin{array}{l}\text { Instructional Technology } \\
\text { and Educational Technology }\end{array}$ & 14 & $\begin{array}{l}\text { Universiti Pendidikan } \\
\text { Sultan Idris (UPSI) }\end{array}$ \\
\hline B & $\mathrm{F}$ & $\mathrm{PhD}$ & Multimedia Education & 5 & $\begin{array}{l}\text { Universiti Pendidikan } \\
\text { Sultan Idris (UPSI) }\end{array}$ \\
\hline $\mathrm{C}$ & $\mathrm{F}$ & $\mathrm{PhD}$ & Educational Technology & 8 & $\begin{array}{l}\text { Universiti Sains } \\
\text { Malaysia (USM) }\end{array}$ \\
\hline $\mathrm{D}$ & M & $\mathrm{PhD}$ & Multimedia & 25 & Universiti Malaya (UM) \\
\hline $\mathrm{E}$ & M & $\mathrm{PhD}$ & Educational Technology & 12 & $\begin{array}{l}\text { Universiti Teknologi } \\
\text { Malaysia (UTM) }\end{array}$ \\
\hline $\mathrm{F}$ & $\mathrm{F}$ & $\mathrm{PhD}$ & $\begin{array}{l}\text { Educational Technology, } \\
\text { Instructional Technology, } \\
\text { and Visual Communication } \\
\text { (Graphic Design) }\end{array}$ & 5 & $\begin{array}{l}\text { Universiti Pendidikan } \\
\text { Sultan Idris (UPSI) }\end{array}$ \\
\hline G & $\mathrm{F}$ & $\mathrm{PhD}$ & $\begin{array}{l}\text { Visual Design and } \\
\text { Multimedia Studies }\end{array}$ & 5 & Universiti Malaya (UM) \\
\hline $\mathrm{H}$ & M & $\mathrm{PhD}$ & $\begin{array}{l}\text { Instructional Technology } \\
\text { and Mobile Learning }\end{array}$ & 10 & $\begin{array}{l}\text { Universiti Sains } \\
\text { Malaysia (USM) }\end{array}$ \\
\hline I & $\mathrm{F}$ & $\mathrm{PhD}$ & $\begin{array}{l}\text { Instructional Technology, } \\
\text { Behavioral Studies, and } \\
\text { Human and Computer } \\
\text { Interaction }\end{array}$ & 18 & $\begin{array}{l}\text { Universiti Sains } \\
\text { Malaysia (USM) }\end{array}$ \\
\hline $\mathrm{J}$ & $\mathrm{F}$ & $\mathrm{PhD}$ & $\begin{array}{l}\text { Information Management, } \\
\text { Knowledge Management, } \\
\text { and Research Method } \\
\text { (Children) }\end{array}$ & 21 & $\begin{array}{l}\text { Universiti Teknologi } \\
\text { Mara (UiTM) }\end{array}$ \\
\hline K & M & $\mathrm{PhD}$ & Instructional Design & 40 & $\begin{array}{l}\text { University of Twente, } \\
\text { Netherlands. }\end{array}$ \\
\hline
\end{tabular}

Note: $\mathrm{F}=$ Female $\mid \mathrm{M}=$ Male.

Data collection procedure and instrument. The expert review process begins with sending an email invitation to the identified experts. Once the expert has agreed to be a reviewer, they will be given an official letter of appointment as well as a consent 
form. Once the consent form has been completed with the signature and officially stamped by the expert, a set of review instruments will be emailed for the evaluation process. The review instrument consists of an illustration of proposed components and also a review form. The experts were given around two to three weeks to complete the instrument form and required to return the document through email. The review instrument was adapted from [49]-[51], which contains three main sections. The instrument is composed of review questions that address the following: i) the relevance of the proposed components, sub-components and elements, ii) the understandability of the terms used, iii) the logical relationship and flow of the proposed model's main components and sub-components, and (v) the readability of the proposed model. The experts were assigned a specific column to make further comments or suggestions about the proposed component and element. Three response alternatives are presented, including "some are definitely not relevant", "some may be not relevant", and "all are relevant". Experts can select their preferred response.

\section{$4 \quad$ Results and discussion}

Table 5 tabulates the data gathered in the reviewing process from the experts. Additionally, some experts provide further comments and suggestions in reviewing the proposed elements. It means that some of the elements of the Edutainment Feature and Activity component need clarity in terms of meaning and suitability. The expert review process, however, takes a long time to complete. When the country is dealing with a pandemic COVID-19, the process is being carried out, limiting face-to-face meetings with the experts. Besides, the selected experts have restricted free time due to other work commitments as most of the works are conducted online.

Table 5. Frequencies of responses from the experts reviewer

\begin{tabular}{|c|c|c|c|c|}
\hline \multirow{5}{*}{ Q1 } & \multirow{2}{*}{$\begin{array}{c}\text { The Proposed Elements in } \\
\text { Edutainment Feature are } \\
\text { Relevant }\end{array}$} & \multicolumn{3}{|c|}{ Frequency $(n=11)$} \\
\hline & & $\begin{array}{c}\text { Some are Definitely } \\
\text { not Relevant }\end{array}$ & $\begin{array}{l}\text { Some may be } \\
\text { not Relevant }\end{array}$ & $\begin{array}{l}\text { All are } \\
\text { Relevant }\end{array}$ \\
\hline & Musical Interest & 2 & 1 & 8 \\
\hline & Speech Element & 1 & 1 & 9 \\
\hline & Character Representation & 0 & 2 & 9 \\
\hline \multirow{4}{*}{ Q2 } & $\begin{array}{c}\text { The Proposed Elements in } \\
\text { Activity are Relevant }\end{array}$ & $\begin{array}{c}\text { Some are Definitely } \\
\text { not Relevant }\end{array}$ & $\begin{array}{l}\text { Some may be } \\
\text { not Relevant }\end{array}$ & $\begin{array}{l}\text { All are } \\
\text { Relevant }\end{array}$ \\
\hline & Social Interactivity & 0 & 3 & 8 \\
\hline & Interactive Questioning & 0 & 1 & 10 \\
\hline & Expand Learning Space & 2 & 0 & 9 \\
\hline
\end{tabular}

Note: Q1 = Question $1 \mid \mathrm{Q} 2=$ Question 2 .

For the component of the Edutainment Feature, Expert $\mathrm{C}$ suggested using a suitable character for children. This study accepts the recommendation from the expert to make 
the element of "character representation" more meaningful. Answering this comment, this study agrees to include a new principle of this element which is "use a character that shows a good and positive trait". Other than that, Expert K argues the meaning of "musical interest". The expert points out the definition of "musical interest" is unclear. However, this element does convey its true meaning, which refers to the appeal of musical sound in the video that can attract learners' interest. Therefore, in responding to this comment, the commented term is retained.

Meanwhile, for Activity component, Expert B suggested adding "virtual interactivity" due to pandemic issues to support home-based teaching and learning (PdPR) as most of the learning conducted online. Though the suggestion is helpful, it is not suitable for this component as the pandemic issue that impacted the learning situation is temporary. Therefore, this suggestion is not considered in the revision process. Besides, Expert C argues that "interactive questioning" should be intuitive. The element of "interactive questioning" refers to how the questions were asked in the video. In response to this comment, the suggestion does not refer to this element's particular meaning. However, this study considers to include the strategies for promoting active learning recommended by [33], which suitable to be adapted in the revision process. Besides, the term was changed to "effective questioning" to make it clearer. So, the added principle for this element is "use guiding question".

Furthermore, Expert I and K argues the difficulty to measure "expand learning space", which refers to the ability of the learner to create their imagination. This study admits this impairment logically since only students can define their capability. Therefore, this study takes this comment positively and discard this element as an improvement for the model. On top of that, for "social interactivity", Expert G and Expert I questioned its relevancy in the model and how it can be achieved while learning. In regard to this comment, this study admits that the explanation of this element is unclear as the word "social" refers to a group of people instead of the individual. Besides, it is contradicted to the situation where the learner tends to use the EMV for self-study purposes. Due to that, this study provides the options for this element which is "self-learning" and "group-learning". As for the term of this element, it is more appropriate to rename it into "audience interactivity" that explains how it can happen in group of learners as referred to its original intent.

Based on the clarification of the mentioned comments from the experts, the elements for audio criteria were revised and updated accordingly. Figure 2 show the validated component and elements of Edutainment Feature and Activity.

\section{Conclusion}

In conclusion, implementing the edutainment approach in learning, particularly in educational videos, has positively impact the students. Numerous previous studies have established the efficacy of edutainment in the classroom, utilising various platforms and media kinds [52]. 


\section{EDUTAINMENT FEATURE}

EmotionalAttraction

Musical Interest

Speech Element

Character Representation

Use character that show a good and positive trait

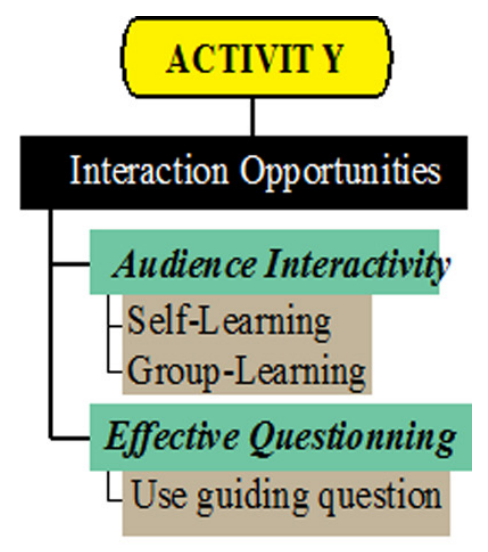

Fig. 2. Validated sub-component and elements of edutainment feature and activity

It is not to argue the degree of skill of students who experienced the learning process without edutainment. To some extent, edutainment is still recognised as having the potential to bring value to students' learning experiences. In line with that, two objectives were defined in this study: i) to ascertain the significance of the edutainment concept in learning and its impact on students, and ii) to conduct comparative analysis to discover the component and element of edutainment in EMV for children's learning. Based on extensive literature review on edutainment for educational videos, it is clear that edutainment in learning can have substantial impacts on students, including the following; i) develop critical-creative thinking skills, increase engagement, and change the transition from fixed to a growth mindset (for mathematical solving skill in particular); ii) develop a more positive emotional state; iii) increase student's retention in learning; iv) engage students in learning physically and mentally; v) help students increase their focus level in the learning process, and vi) promote long term memory recall. Having explored the significance of edutainment in educational videos particularly to emphasis its significance during COVID-19 pandemic, a comparative analysis was conducted to achieve the second objective of this paper. This analysis aims to identify and propose educational components and elements in EMV for children's learning. Following that, the proposed elements were evaluated by an expert review process in which 11 experts from related domains consented to participate. The proposed features have been amended in response to expert comments and suggestions, and the validated elements of edutainment for EMV are presented at the end of Section 4. In light of the relatively small scale of this present study, future research should incorporate evaluation testing for instructor who could use EMV as learning support media.

\section{Acknowledgment}

Special thanks to the Creative Industry International Conference (CIIC) 2020 organised by the School of Creative Industry Management and Performing Arts, Universiti 
Utara Malaysia. Additionally, we would like to thank the Ministry of Higher Education (MoHE) for financial support throughout the research study.

\section{$7 \quad$ References}

[1] Cheristiyanto, C. (2021). The effectiveness of video-based learning media to increase student economic learning outcomes during the Covid-19 pandemic. Economic Education Analysis Journal, 10(3): 394-403. https://doi.org/10.15294/eeaj.v10i3.47899

[2] Sholeh, M., Suraya, S., \& Andayani, D. (2021). Learning at home during the Covid-19 pandemic by optimizing video based tutorials. INTENSIF: Jurnal Ilmiah Penelitian dan Penerapan Teknologi Sistem Informasi, 5(2): 206-217. https://doi.org/10.29407/intensif. v5i2.15348

[3] Joko Prayudha, S. (2021). Video based learning as a media for teaching english during pandemic Covid-19. Journal of Language Intelligence and Culture, 2(1): 1-11. https://doi. org/10.35719/jlic.v2i1.53

[4] Giannakos, M. N. (2013). Exploring the video-based learning research: A review of the literature. British Journal of Educational Technology, 44(6): E191-E195. https://doi.org/10.1111/ bjet. 12070

[5] Winslett, G. (2014). What counts as educational video?: Working toward best practice alignment between video production approaches and outcomes. Australasian Journal of Educational Technology, 30(5). https://doi.org/10.14742/ajet.458

[6] Veenstra, B., Van Geert, P. L. C., \& Van der Meulen, B. F. (2011). Is edutainment software really educational? A feature analysis of Dutch edutainment software for young children. Netherlands Journal of Psychology, 66(2): 50-67.

[7] Dandashi, A., Karkar, A. G., Saad, S., Barhoumi, Z., Al-Jaam, J., \& El Saddik, A. (2015). Enhancing the cognitive and learning skills of children with intellectual disability through physical activity and edutainment games. International Journal of Distributed Sensor Networks, 11(6): 165165. https://doi.org/10.1155/2015/165165

[8] Haddad, N. A. (2014). Heritage multimedia and children edutainment: assessment and recommendations. Advances in Multimedia, 2014. https://doi.org/10.1155/2014/579182

[9] Rusman, N. S., \& Ismail, H. N. (2020, February). City edutainment for educational and social justice for early childhood. In IOP Conference Series: Earth and Environmental Science (Vol. 447, No. 1, p. 012008). IOP Publishing. https://doi.org/10.1088/1755-1315/ 447/1/012008

[10] Colace, F., De Santo, M., Pietrosanto, A., \& Troiano, A. (2006, October). Work in progress: Bayesian networks for edutainment. In Proceedings. Frontiers in Education. 36th Annual Conference (pp. 13-14). IEEE. https://doi.org/10.1109/FIE.2006.322573

[11] Druin, A., \& Solomon, C. (1996). Designing multimedia environments for children: Computers, creativity, and kids. John Wiley \& Sons, Inc.

[12] Isa, W. M. W., Amin, M. A. M., Rozaimee, A., Idris, W. M. R. W., Rahim, N., \& Samaden, I. S. (2015). Conceptual framework of edutainment animated series for children: A pious story. ARPN Journal of Engineering and Applied Sciences, 10(3): 1106-1113.

[13] Pasawano, T. (2015). Results of enhanced learning with the edutainment format. Procedia-Social and Behavioral Sciences, 176: 946-951. https://doi.org/10.1016/j.sbspro.2015.01.563

[14] Creighton, M. R. (1994). "Edutaining" children: consumer and gender socialization in Japanese marketing. Ethnology, 33(1): 35-52. https://doi.org/10.2307/3773973

[15] Barrey, S., Baudrin, M., \& Cochoy, F. (2010). From fun foods to fun stores. Young Consumers, 11(2): 138-147. https://doi.org/10.1108/17473611011065827 
[16] Savidis, A., Grammenos, D., \& Stephanidis, C. (2007). Developing inclusive e-learning and e-entertainment to effectively accommodate learning difficulties. Universal Access in the Information Society, 5(4): 401-419. https://doi.org/10.1007/s10209-006-0059-3

[17] Carter, C. M. (2016). The Complete Guide to Generation Alpha, The Children of Millennials. Forbes. [Online]. Available: https://www.forbes.com/sites/christinecarter/2016/12/21/thecomplete-guide-to-generation-alpha-the-children-of-millennials/?sh=2cb9298e3623

[18] Okan, Z. (2003). Edutainment: Is learning at risk? British Journal of Educational Technology, 34(3): 255-264. https://doi.org/10.1111/1467-8535.00325

[19] Korkmaz, Ş. Ç. (2013). Language games as a part of edutainment. Procedia-Social and Behavioral Sciences, 93: 1249-1253. https://doi.org/10.1016/j.sbspro.2013.10.023

[20] Tasuah, N., \& Diana, D. (2017, December). The Implementation of Edutainment Method in Preschool Learning. In International Conference of Early Childhood Education (ICECE 2017) (pp. 281-283). Atlantis Press. https://doi.org/10.2991/icece-17.2018.72

[21] Chilingaryan, K., \& Zvereva, E. (2020). Edutainment as a new tool for development. International E-Journal of Advances in Education, 6(16): 111-119. https://doi.org/10.18768/ $\underline{10.18768 / \text { ijaedu. } 616015}$

[22] Makarius, E. E. (2017). Edutainment: Using technology to enhance the management learner experience. Management Teaching Review, 2(1): 17-25. https://doi.org/10.1177/ 2379298116680600

[23] Hadi, M. S. (2019). The use of song in teaching English for junior high school student. English Language in Focus (ELIF), 1(2): 107-112. https://doi.org/10.24853/elif.1.2.107-112

[24] Nemec, J., \& Trna, J. (2007). Edutainment or Entertainment Education Possibilities of Didactic Games in Science Education. In ICCP Word Play Conference (pp. 55-64). Brno: Masaryk University.

[25] Lynch-Arroyo, R., \& Asing-Cashman, J. (2016). Using edutainment to facilitate mathematical thinking and learning: An exploratory study. Journal of Mathematics Education, 9(2): $37-52$.

[26] Steffes, E. M., \& Duverger, P. (2012). Edutainment with videos and its positive effect on long term memory. Journal for Advancement of Marketing Education, 20(1): 1-10.

[27] Mindu, T., Kabuyaya, M., \& Chimbari, M. J. (2020). Edutainment and infographics for schistosomiasis health education in Ndumo area, Kwazulu-Natal, South Africa. Cogent Medicine, 7(1): 1794272. https://doi.org/10.1080/2331205X.2020.1794272

[28] Adnyani, L. D. S., Suprianti, G. A. P., Marsakawati, N. P. E., \& Narotama, P. D. A. (2020). Powtoon as the Implementation of Edutainment for Young Learners. In Proceedings of the 2nd International Conference on Technology and Educational Science (ICTES 2020). https:// doi. org/10.2991/assehr. k (Vol. 210407). https://doi.org/10.2991/assehr.k.210407.239

[29] Cayari, C. (2014). Using informal education through music video creation. General Music Today, 27(3): 17-22. https://doi.org/10.1177/1048371313492537

[30] Marone, V. (2018). Teaching English through music videos. The TESOL Encyclopedia of English Language Teaching, 1-7. https://doi.org/10.1002/9781118784235.eelt0849

[31] Abbott, M. (2002). Using music to promote L2 learning among adult learners. TESOL Journal, 11(1): 10-17.

[32] Beasley, R. E., \& Chuang, Y. (2008). Web-based music study: The effects of listening repetition, song likeability, and song understandability on EFL learning perceptions and outcomes. TESL-EJ, 12(2): n2.

[33] Brame, C. J. (2016). Effective educational videos: Principles and guidelines for maximizing student learning from video content. CBE-Life Sciences Education, 15(4): es6. https://doi. org/10.1187/cbe.16-03-0125

[34] Taspolat, A., Kaya, O. S., \& Sapanca, H. F. (2018). Characteristics of instructional videos. World Journal on Educational Technology: Current Issues, 10(2): 79-87. https://doi.org/ 10.18844/wjet.v10i2.3418 
[35] Carmichael, M., Reid, A., \& Karpicke, J. D. (2018). Assessing the impact of educational video on student engagement, critical thinking and learning. Sage Publishing. Retrieved from https://us.sagepub.com/sites/default/files/hevideolearning.pdf

[36] Buchner, J. (2018). How to create Educational Videos: From watching passively to learning actively. R\&E-SOURCE, 12: 1-10.

[37] Shoufan, A. (2019). What motivates university students to like or dislike an educational online video? A sentimental framework. Computers \& Education, 134: 132-144. https://doi. org/10.1016/i.compedu.2019.02.008

[38] Moussiades, L., Kazanidis, I., \& Iliopoulou, A. (2019). A framework for the development of educational video: An empirical approach. Innovations in Education and Teaching International, 56(2): 217-228. https://doi.org/10.1080/14703297.2017.1399809

[39] van der Meij, H., \& van der Meij, J. (2013). Eight guidelines for the design of instructional videos for software training. Technical Communication, 60(3): 205-228.

[40] Thomson, A., Bridgstock, R., \& Willems, C. (2014). 'Teachers flipping out' beyond the online lecture: Maximising the educational potential of video. Journal of Learning Design, 7(3): 67-78. https://doi.org/10.5204/jld.v7i3.209

[41] Guo, P. J., Kim, J., \& Rubin, R. (2014, March). How video production affects student engagement: An empirical study of MOOC videos. In Proceedings of the first ACM conference on Learning@ scale conference (pp. 41-50). https://doi.org/10.1145/2556325.2566239

[42] Voronkin, O. (2019, June). Educational Video in the University: Instruments, Technologies, Opportunities and Restrictions. In ICTERI (pp. 302-317).

[43] Korkut, S., Dornberger, R., Diwanji, P., Simon, B. P., \& Märki, M. (2015). Success factors of online learning videos. International Journal of Interactive Mobile Technologies, 9(4): 17-22. https://doi.org/10.3991/ijim.v9i4.4460

[44] Oliver, L. (2019). Basic Design Principles for Effective Video-based Learning, 2016. [Online]. Available: https://medium.com/@lianabeloliver/basic-design-principles-for-effective-video-based-learning-327aed40dcfb. [Accessed: 29-Oct-2019].

[45] Oujezdský, A. (2013). Creation of educational video tutorials and their use in education. ICTE Journal, 3(1): 28-39. https://doi.org/10.1515/ijicte-2014-0003

[46] Kuśnierek, A. (2016). The role of music and songs in teaching English vocabulary to students. World Scientific News, 1(43): 1-55.

[47] Keeney, R. L., \& Von Winterfeldt, D. (1991). Eliciting probabilities from experts in complex technical problems. IEEE Transactions on Engineering Management, 38(3): 191-201. https://doi.org/10.1109/17.83752

[48] Wolfenstetter, T., Füller, K., Böhm, M., Krcmar, H., \& Bründl, S. (2015, October). Towards a Requirements Traceability Reference Model for Product Service Systems. In 2015 International Conference on Industrial Engineering and Systems Management (IESM) (pp. 1213-1220). IEEE. https://doi.org/10.1109/IESM.2015.7380307

[49] Azman, F. N., Zaibon, S. B., \& Shiratuddin, N. (2018). A Revised Production Model of Learner-generated Comic: Validation Through Expert Review. In MATEC Web of Conferences (Vol. 150, pp. 1-6). EDP Sciences. https://doi.org/10.1051/matecconf/ 201815005044

[50] Pendit, U. C. (2016). Conceptual model of mobile augmented reality for cultural heritage site towards enjoyable informal learning (Marchsteil) (Doctoral dissertation, Universiti Utara Malaysia).

[51] Siti Zulaiha, A. (2017). A Conceptual Model of Interactive Computer Assisted Learning for Low Achieving Primary School Student, Universiti Utara Malaysia.

[52] Karakose, T., Yirci, R., \& Papadakis, S. (2021). Exploring the interrelationship between covid-19 phobia, work-family conflict, family-work conflict, and life satisfaction among school administrators for advancing sustainable management. Sustainability, 13(15): 8654. https://doi.org/10.3390/su13158654 


\section{Authors}

Hanis Salwani Othman owned a bachelor's degree in Multimedia at Universiti Utara Malaysia (UUM) in 2014 and a Master in Creative Industries majoring in Interactive and Visual Design at Queensland University of Technology, Australia in 2017. She currently pursuing a PhD degree in Universiti Utara Malaysia. Her research interest is related to Multimedia studies, Education Entertainment, and Educational Technology and Media.

Syamsul Bahrin Zaibon is an Associate Professor of Creative Media and Deputy Dean at the School of Creative Industry Management \& Performing Arts, Universiti Utara Malaysia (UUM) and teaches various courses in the areas of creative industry and media interactive. He holds a $\mathrm{PhD}$ in Multimedia from UUM. His research is diverse and focuses on multimedia \& mobile applications, web design $\&$ development, game-based learning, comics for learning, and edutainment. E-mail: syamsulbahrin@, uum.edu.my

Ahmad Hisham Zainal Abidin is a Senior Lecturer and Dean at the School of Creative Industries Management and Performing Arts, Universiti Utara Malaysia (UUM). He received a bachelor degree and a master in Information Technology at UUM and $\mathrm{PhD}$ degree in Information Technology at Murdoch University, Australia, in 2016. He is interested in investigating the potential of touch screen devices to be used by blind people in their daily lives and currently working on research in this area under the Fundamental Research Grant Scheme (FRGS), Ministry of Education Malaysia. E-mail: hishamza@uum.edu.my

Article submitted 2021-05-04. Resubmitted 2021-11-19. Final acceptance 2021-12-09. Final version published as submitted by the authors. 